\title{
ALTERAÇÃO SUPERFICIAL E PEDOGEOMORFOLOGIA NO SUL DO COMPLEXO BAÇÃO - QUADRILÁTERO FERRÍFERO (MG) $)^{(\mathbf{1})}$
}

\author{
M. A. FIGUEIREDO(2), A. F. D. C. VARAJ ÃO(2), J . D. FABRIS(3), \\ I. S. LOUTFI(2) \& A. P. CARVALHO(2)
}

\begin{abstract}
RESUMO
Alguns aspectos dos processos de alteração superficial e seus reflexos na pedogeomorfologia Quaternária na sub-bacia do alto Ribeirão Maracujá, no Complexo Bação, Quadrilátero Ferrífero, MG, são aqui caracterizados. São investigados caracteres relativos à dinâmica evolutiva de três vertentes (toposseqüências 1, 2 e3), situadas sobre gnaisses, mas com graus de erodibilidade diferenciados. Nos segmentos de alta vertente das toposseqüências 1 e 2, os perfis de solos são pouco desenvolvidos e autóctones. Na toposseqüência 3, no mesmo segmento, ocorre um L atossolo com feições de aloctonia. Nos segmentos de meia vertente, das três toposseqüências ocorrem perfis latossólicos espessos, desenvolvidos a partir de sedimentos coluviais provindos da alta vertente. Nos segmentos de baixa vertente, há ruptura nos processos de transporte e deposição dos sedimentos, sendo o perfil de solo da toposseqüência 2 um Latossolo Câmbico autóctone e, nas toposseqüências 1 e 3, perfis desenvolvidos a partir de materiais alúvio-coluviais depositados sobre o saprolito gnáissico. Apesar de a dinâmica evolutiva das três vertentes corroborar os modelos geomorfológicos tropicais até o segmento de meia vertente, a jusante, a ruptura do coluvionamento na baixa vertente evidencia um recente desequilíbrio morfodinâmico. Além disso, as evidências micromorfológicas e mineralógicas não sinalizam correlação com susceptibilidade erosiva diferenciada verificada na área.
\end{abstract}

Termos de indexação: intemperismo, micromorfologia, solos gnáissicos.

(1) Trabalho referente à parte da Tese de Doutorado em Geociências do primeiro autor, em desenvolvimento no Departamento de Geol ogia, Escola de Minas, Universidade Federal de Ouro Preto - UFOP. Recebido para publicação em outubro de 2002 e aprovado em abril de 2004.

(2) Professora Adjunta e Bolsistas de Iniciação Científica do Departamento de Geologia, Escola de Minas, Universidade Federal de Ouro Preto - UFOP. Campus Morro do Cruzeiro, CEP 35400-000 Ouro Preto (MG). E-mail: m67f@yahoo.com.br; angelica@degeo.ufop.br

(3) Professor Titular do Departamento de Química, Instituto de Ciências Exatas, Universidade Federal de Minas Gerais - UFMG. Campus Pampulha, CEP 31270-901 Belo Horizonte (MG) E-mail: jdfabris@ufmg.br 


\title{
SUMMARY: SUPERFICIAL ALTERATION AND PEDOGEOMORPHOLOGY IN THE SOUTH OF THE BAÇÃO COMPLEX - QUADRI LÁTERO FERRÍFERO - MG, BRAZIL
}

\begin{abstract}
This study defines someaspects of superficial alteration processes and their reflexes on the Quaternary pedogeomorphology in the sub-basin of the upper Maracujá River, in the Compl exo Bação, ferriferous zone, State of Minas Gerais, Brazil. Characteristics related to the dynamic evol ution of threegneiss-underlayered toposequences $(1,2$, and 3$)$ at different erosi on stages were investigated. In thetop sl ope segments of thetoposequences 1 and 2 the soil profiles arelittle devel oped and present an in situ evol ution. In toposequence 3, the soi I profil eof thesametop sl opesegment is a well devel oped Oxisol with al lochthonous features. Similarly, in the mid slope segments of the three toposequences, the soil profiles are thick, L atosol ic, originated from thecoll uvial sediments that descended from thetop sl ope. However, thereis a rupturein thesediment transport and deposition process in thelow slopesegments. The soil profile of toposequence 2 is an autochthonous Cambic Oxisol, while the toposequences 1 and 3 profiles were devel oped from all uvial - col luvial materials deposited on thegneiss saprol ite basement. Despitethefact that dynamic evol ution of thetop and mid slopesegments of thethreetoposequences corroboratethetropical geomorphol ogical models up to the mid sl ope segment, therupture in colluvial deposition to thelower slopesegments suggests a recent morphodynamic imbalance. Besides, the micromorphological and mineralogical features do not present any correlation with the differentiated erosive susceptibility verified in the area.
\end{abstract}

Index terms: weathering, mi cromorphol ogy, gneiss soils.

\section{NTRODUÇÃO}

A evolução da paisagem de ambientes tropicais tem sido bem estudada, principalmente quanto ao intemperismo químico, fator preponderante nos processos de denudação geoquímica (Millot, 1983; Thomas, 1994a). Vários aspectos têm si do abordados e, entre eles, o estádio de desenvolvimento do solo como indicador de variações na dinâmica geomorfológica ao longo do tempo (Thomas, 1994a,b; Figueiredo, 1999; Figueiredo et al., 1999; VidalTorrado \& Lepsch, 1999). O estádio de intemperismo dos solos está intimamente ligado a processos climáticos e, ou, tectônicos.

Do ponto de vista climático, os solos, quando expostos a ambientes úmidos (tropicais), são alvo de intenso intemperismo químico responsável pela rápida transformação dos minerais primários (Lucas \& Chauvel, 1992; Macias \& Chesworth, 1992). No entanto, mesmo em condições de intenso intemperismo químico, muitos solos de regiões úmidas tropicais ainda externam uma correlação mineralógica e morfológica direta com as características da rocha mãe (Macias \& Chesworth, 1992).

Pelo lado tectônico, determinada região, ao ser submetida a soerguimentos cíclicos, possibilita o encaixamento da rede de drenagem local, visto que, em busca dereequilíbrio com onível de base regional, os cursos fluviais tendem a incidir verticalmente os vales (encaixamento), desencadeando, por sua vez, um aumento no gradiente de declividade das vertentes. São geradas as condições para intensificação da erosão, sobretudo nos segmentos de alta e média vertente. No segmento de baixa vertente, são provocados desequilíbrios hidrológicos de subsuperfície, onde o nível da zona piezométrica também se rebaixa, em busca do equilíbrio com o perfil fluvial em mutação. A água, movimentandose ao longo de planos de fraturas, concentrar-se-ia subsuperficialmente e desencadearia erosão linear acelerada (voçorocas).

Nesta perspectiva, haveria um rebaixamento generalizado na paisagem, com a retirada (erosão) de grande parte da massa dos horizontes superficiais. Com a proximidade do front de intemperismo em alguns segmentos de vertente, haveria um rejuvenescimento pedogenético, cujos horizontes $B$ atuais manteriam características de parentesco com o substrato rochoso e, ou, saprolítico (autoctonia). Entretanto, nãohá dados suficientes que demonstrem, de maneira inquestionável, sua ocorrência na área de investigação deste trabalho.

No Complexo Bação, Quadrilátero Ferrífero, particularmente na sua área sul, ocorrem vertentes com baixa declividade em cujo eixo desenvolvem-se solos de origem gnáissica (rocha predominante na área), com diferentes graus de alteração. As características mineralógicas desses sol os foram estudadas apenas por Parzanese (1991), cujo trabalho objetivou a relação entre natureza pedológica e gênese de voçorocas na região.

Os solos da área em questão são considerados como Latossol os Vermelho-Amarelos distróficos (Cetec-MG, 1983), Latossolos Vermelho-Escuros e Cambissol os álicos (Radambrasil, 1983). Conforme Parzanese (1991), os Latossol os Vermel ho-Amarelos são dominantes, indicando perfis bastantelixiviados. 
Nos locais de relevo mais suave, predominam os Latossol os; nas zonas deinterflúvios, ocorrem muitos Cambissol os com forte influência da rocha parental gnáissica. O solo é pouco espesso na alta vertente (litólico/câmbico), espesso na meia (latossólico) e novamente pouco espesso na baixa vertente (latossólico/câmbico).

A correlação pedogeomorfológica entre solos alóctones e solos autóctones é de fundamental importância para a interpretação dos estádios de evolução dos perfis de intemperismo e das vertentes (Queiroz Neto, 2000). Sabe-se que com os ciclos de erosão e sedimentação verificados na região durante o Quaternário (Valadão \& Silveira, 1992), os solos produzidos nas zonas de interflúvio foram transportados (gravitacionalmente ou através de erosão hídrica) e depositados em vários pontos da vertente. Nos solos pedologicamente evoluídos da região, Bacellar (2000) relata ter sido impossível determinar, com segurança, a gênese desses solos, se eluvial ou coluvial. Entretanto, o autor supracitado não se val eu da utilização de estudos mi cromorfológicos que, provavel mente, poderiam ajudar a elucidar tal indagação. Aspectos micromorfológicos, tais como: a organização do fundo matricial, as características texturais dos grãos esquel etais e as microfeições (Brewer, 1976; Eswaran \& Stoops, 1979; Bullock et al., 1985; Castro, 1999, Sander, 2002), podem determinar a natureza do geomaterial investigado, inclusive quanto à sua susceptibilidade à erosão (Castro, 1999).

No intuito de contribuir para o entendimento da evolução recente dos sol os da região em questão, faz- se uma avaliação da alteração superficial e da pedogeomorfologia, a partir de estudos macromorfológicos e micromorfológicos, obtidos de análises mineralógicas, químicas efísicas dos materiais.

\section{CARACTE RIZAÇÃO DA ÁREA}

A área de estudo localiza-se no sul do Complexo Bação, entreos paralel os $20^{\circ} 2000^{\prime \prime}$ e20 $23^{\prime} 16^{\prime \prime} \mathrm{S}$ e os meridianos $43^{\circ} 38^{\prime} 32^{\prime \prime}$ e $43^{\circ} 42^{\prime} 16^{\prime \prime} \mathrm{W}$, abrangendo aproximadamente $38,4 \mathrm{~km}^{2}$. O Compl exoBação encontra-senoSSE do Quadrilátero Ferrífero- QF (Figura 1), no estado de Minas Gerais, sudeste do Brasil, e constitui o embasamento cristalino granito-gnáissico-migmatítico das unidades geológicas do Quadrilátero Ferrífero. Tal complexo é caracterizado como gnaisse Funil (Salaroli, 1999; Vilela, 1999) etem como características básicas: composição gl obal granodiorítica, com bandas tonalítica (bandas escuras) e granitóide rica em quartzo (bandas claras) (Salaroli, 1999; Vilela, 1999; Bacellar, 2000). Os minerais predominantes são o quartzo e os plagioclásios, que sealternam em faixas de enriquecimento, ora mai or em quartzo, ora maior em plagioclásio. As bandas enriqueci das em quartzo (55\% em volume, conforme Salaroli, 1999), são, muitas vezes, resistentes ao encaixamento da drenagem e dissecação do relevo, mantendo-o em níveis de base locais (Bacellar, 2000).

A geomorfologia da área pode ser descrita como uma paisagem de colinas policonvexas de baixa

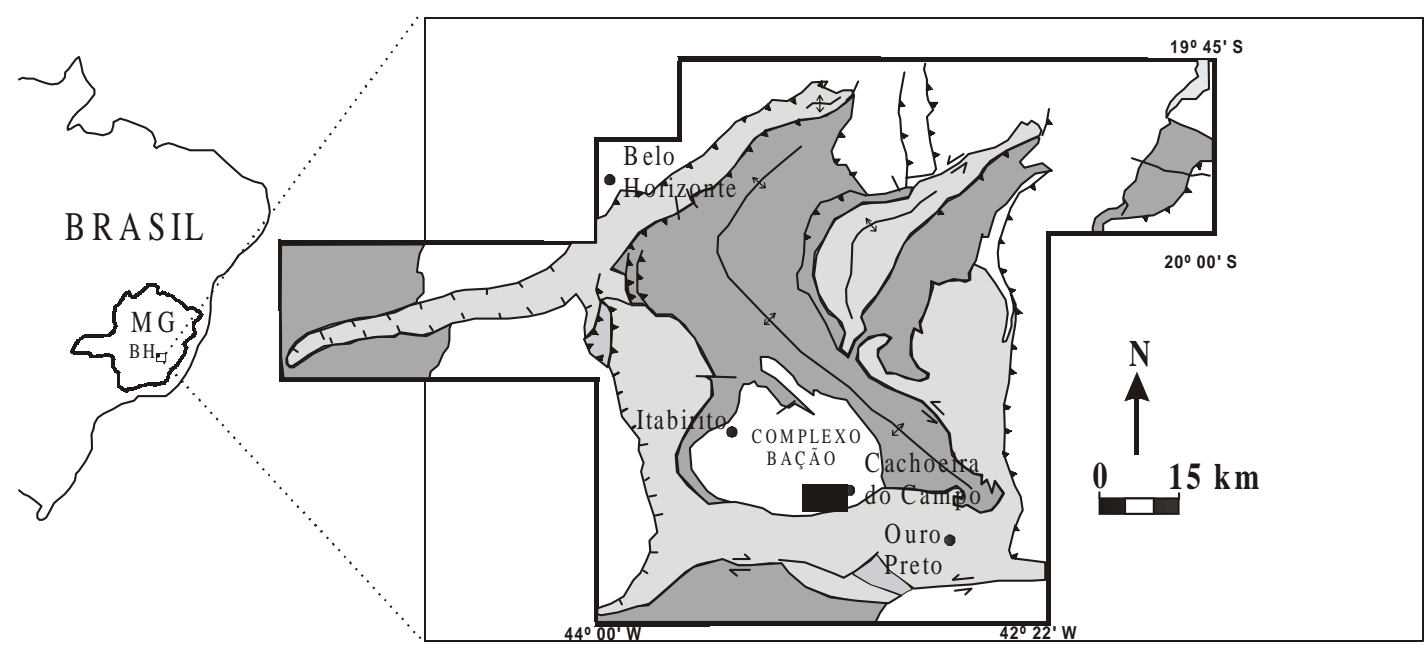

LEGENDA:

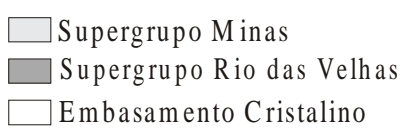

$$
\begin{array}{ll}
\ldots \text { Falha de empurrão } & * \text { Sinclinal } \\
\rightleftharpoons \text { Falha Transcorrente } & \uparrow \text { Anticlinal } \\
\Perp \text { Falha Normal } & \text { Área de Trabalho }
\end{array}
$$

Figura 1. Esboço da Geologia do Quadrilátero Ferrífero com o Complexo Bação e área de trabalho assinalados. 
declividade quando no domínio gnáissico. Os regolitos são espessos, com saprolito profundo, demonstrando intensa atuação de intemperismo químico. A rede de drenagem desenvolve-se sob controle estrutural, com planícies fluviais de agradação sedimentar recentes (Bacellar, 2000). Os sedimentos acumulados nas planícies, cujo volume parece ser incompatível com a capacidade de transporte da rede de drenagem, são provenientes do grande número de voçor ocamentos ocorrentes nas vertentes sob domínio gnáissico, evidenciando o processo de agradação. Os cursos fluviais têm profundidade mínima e continuam recebendo grande aporte de sedimentos areno-siltosos. Todos os vales fluviais têm fundo plano - considerando a grande acumulação de sedimentos - e o contato entre a planície fluvial eo segmentos de baixa vertente se dá de forma abrupta, em ruptura de declive.

\section{MATERIAL E MÉTODOS}

A partir do levantamento de campo, precedido de interpretações em fotografias aéreas (escala 1: 25.000) eortofotos (escala 1: 10.000), foram selecionadas três vertentes para esteestudo (Figura 2). A escol ha está relacionada com a área não voçorocada (toposseqüência 1), área de voçorocamento ativo (toposseqüência 2), área de voçorocamento inativo (toposseqüência 3).

Objetivando estabelecer o grau de relacionamento evolutivo entre o substrato rochoso gnáissico e o perfil pedológico nas três vertentes analisadas, na toposseqüência 1 , foram abertas quatro trincheiras nos segmentos de alta vertente, meia vertente superior, meia vertente inferior e baixa vertente (Figura 3a). Na toposseqüência 2, foram abertas três trincheiras, uma em cada segmento de vertente (Figura 3b). A toposseqüência 3 é caracterizada por quatro trincheiras (Figura 3c), seguindo a mesma técnica das vertentes anteriores. As trincheiras apresentaram profundidade média de 1,9 m eforam complementadas com tradagens em diferentes profundidades.

Nas trincheiras, os perfis foram descritos, utilizando-se técnica adaptada de Lemos \& Santos (1996), e foram coletadas amostras deformadas e indeformadas nos diferentes horizontes e suas transições. As análises granulométricas foram

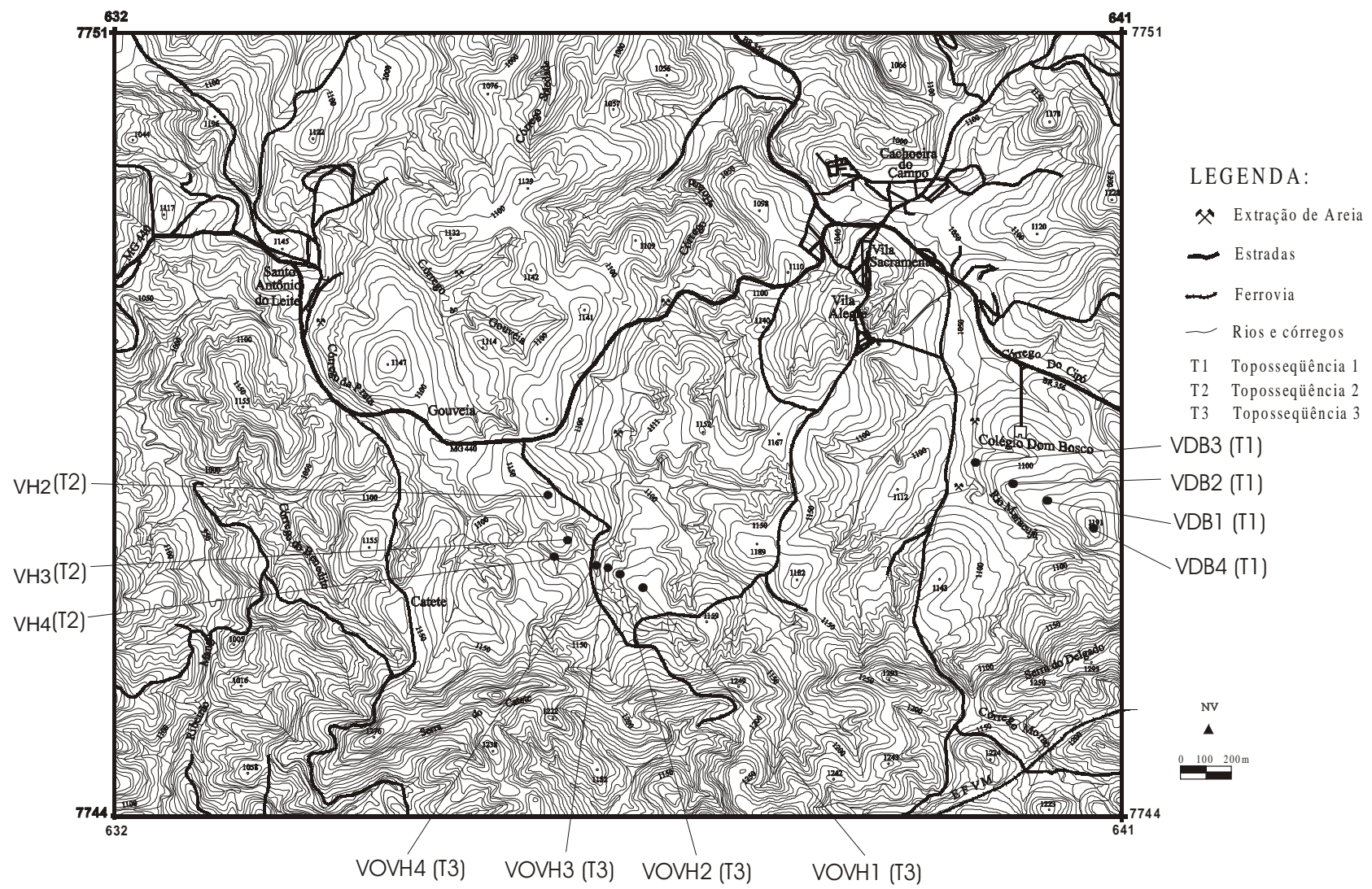

Figura 2. Mapa planialtimétrico da área investigada com as três toposseqüências assinaladas. Toposseqüência 1. VDB4=alta vertente; VDB1 = meia vertente superior; VDB2 =meia vertente inferior; VDB3 = baixa vertente. Toposseqüência 2 . VH2 = alta vertente; VH3 = meia vertente; VH4 = baixa vertente. Toposseqüência 3 . VOVH1 = alta vertente; VOVH2 = meia vertente superior; VOVH $3=$ meia vertente inferior; VOVH4 = baixa vertente. 
(a)
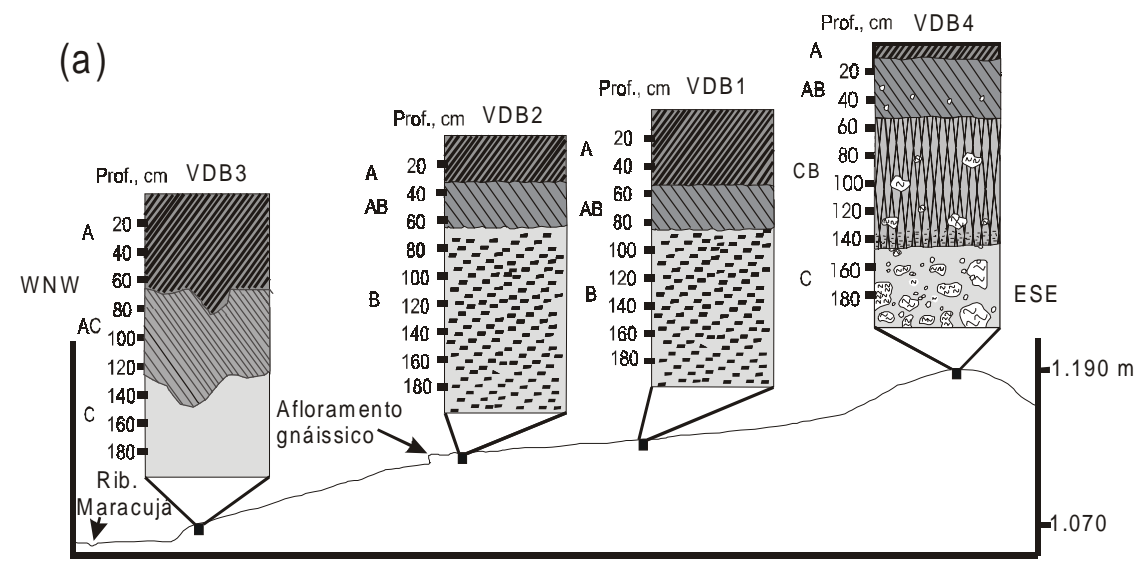

(b)

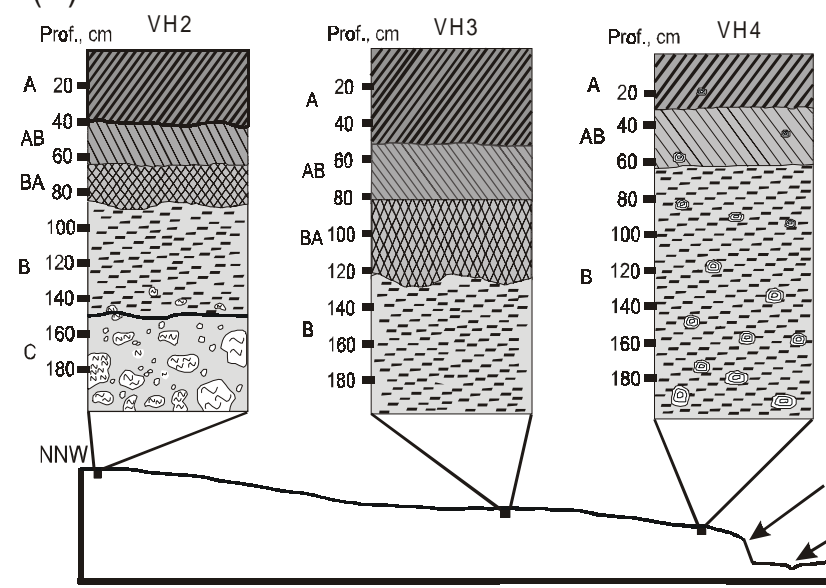

$\mathrm{H} \quad 84 \quad 167250 \mathrm{~m}$
$\mathrm{~V} 204060 \mathrm{~m}$

(c)

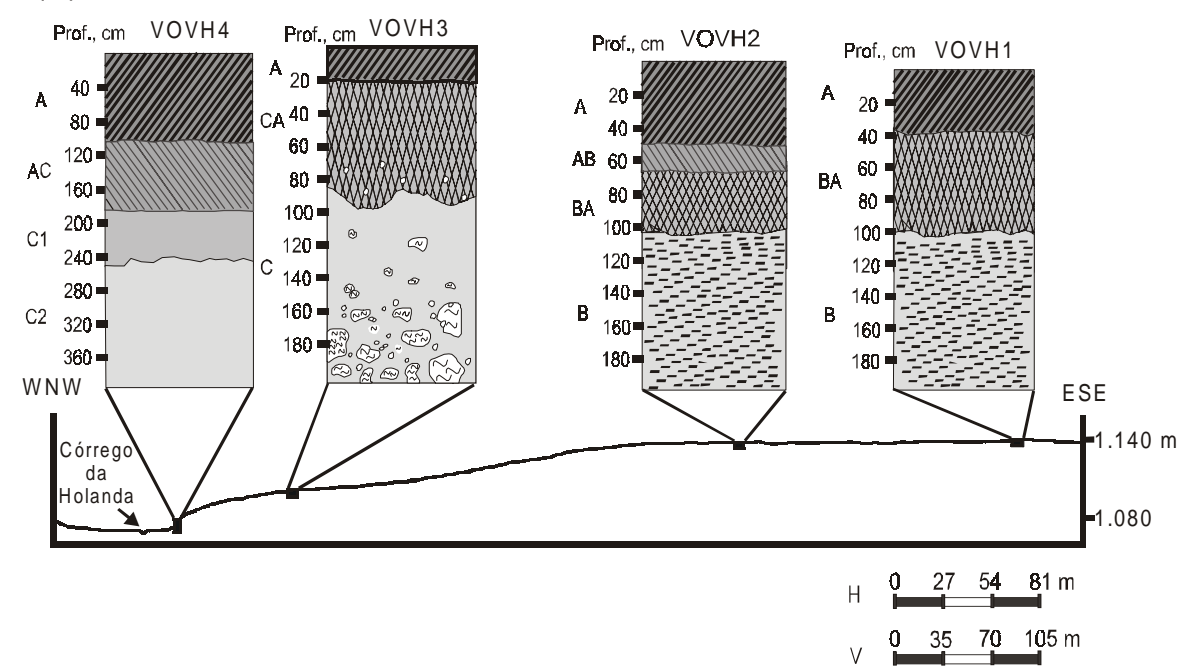

Figura 3. Perfis esquemáticos. (a) = toposseqüência 1; VDB4 = pouco desenvolvido com influência do material parental em todos os horizontes; VDB 1 e VDB2 = Latossolos, cujo materiais constituintes são de natureza alóctone; VDB3 = pouco desenvolvido, oriundo de ambiente redutor fluvial sobre horizonte C parental gnáissico. (b) = toposseqüência 2; VH2 = Cambissolo de natureza autóctone; VH3 = Latossolo de natureza alóctone; VH4 = Latossolo Câmbico de natureza autóctone. (c) = toposseqüência 3; VOVH1 e VOVH2 = Latossolos com manchas lito e pedorreliquiais; VOVH 3 = solo pouco desenvolvido inteiramente sob influência do material parental gnáissico; VOVH3 = Neossolo Flúvico com horizonte $\mathrm{C}$ bastante desferruginizado. 
efetuadas, conforme método da Embrapa-Solos (1997). A análise química total dos elementos maiores (óxidos) foi realizada utilizando-se fluorescência de raios-X em um equipamento Rigaku, modelo 3064. As análises mineralógicas foram efetuadas na fração terra fina, destorroada e passada em peneira de malha de $2 \mathrm{~mm}$, assim como na fração argila, utilizando um difratômetro Rigaku, modelo Geigerflex CN D/MAX-B com tubo de cobre, além do equipamento T.A. Instruments, modelo SDT 2960 para análise térmica diferencial e gravimétrica (ATD/ATG). A análisemicromorfológica foi realizada em dois modelos de microscópio petrográfico com luz polarizada e plana. U m Leica, modelo DMLP, equi pado com câmera digital Nikon, modelo COOLPIX 990, e outro Leitz, modelo Laborlux 12 POL S, equipado com o mesmo equipamento fotomicrográfico. As descrições foram realizadas com base nos métodos de Brewer (1976) eBullock, et al. (1985), além do suportedos trabalhos de Curi, et al. (1985) e Resende, et al. (1997).

\section{RESULTADOS E DISCUSSÃO}

\section{Toposseqüência 1 (VDB)}

Esta toposseqüência (Figuras 2 e3a), representada por quatro perfis pedológi cos (VDB4 +VDB1 +VDB2 + VDB3), corresponde a uma vertente de perfil longitudinal convexo-côncavo, com cobertura vegetal constituída de pastagem plantada dotipoBrachiaria brizantha. Apresenta declividade de $45 \%$ no terço superior; de $15 \%$ no terço médio e de $20-25 \%$ no terço inferior . De acordo com o método preconizado por Lemos \& Santos (1996), a cobertura superficial vai de extremamente a muito pedregosa na alta vertente e pouco a não-pedregosa na meia e baixa vertente. Sítios de afl oramentos do gnaisse com direção de foliação 45 ESE delimitam a variação de declividade da toposseqüência, caracterizando a passagem da meia vertente para a baixa vertente.

Neste segmento de transição, ocorre uma concentração de cascalhos angulosos associados a boulders esparsos de gnaisse. Os solos ocorrentes nesta toposseqüência são pouco desenvolvidos (ausência de horizonte B) na alta vertente, apresentam veios de quartzo e turmalinitos suborizontalizados efragmentados em granulometrias diversas esão bem desenvolvidos eargilosos na meia vertente (horizontes $\mathrm{B}$ profundos). Na baixa vertente, os sol os são pouco desenvol vidos (ausência do horizonte B), gl eizados, argilosos e apresentam feições da atividade fluvial pretérita.

A evolução pedogeomorfológica da toposseqüência 1 indica importantes mudanças na sua dinâmica recente, revelada pelas descrições, macroscópica (Quadro 1) e micromorfológica (Quadro 2), dos principais horizontes. Nosegmento dealta vertente
(VDB4), a pedregosidade da superfície diferenciase dos demais segmentos. É caracterizada por nódulos litorreliquiais gnáissicos, de tamanhos variados (1-3 cm de diâmetro), subarredondados, cuja configuração interna mostra halo ferruginoso (2-3 mm de espessura), envolvendo um núcleo de rocha em mel hor preservação (Figura 4a). J untamse aos nódul os fragmentos de quartzo (de veio) e de turmal initos angulosos, com tamanhos variando de 2 a $15-20 \mathrm{~cm}$. Micromorfologicamente, o horizonte $C$ (Figura 4b) do perfil de alta vertente (VDB4) apresenta bandamento gnáissico reliquial com ferruginizações nas lamelas micáceas e nos bordos efraturas dos quartzos.

No perfil da meia vertente superior (VDB1), a análise mi cromorfol ógica do horizonte B (Figura 4c) evidencia a presença de nódulos litorreliquiais em contato nítido com o plasma argilo-ferruginoso de composi ção caulinita, gibbsita e goethita (Figura 4d). Adicionalmente, a presença de um esqueleto predominantemente quartzoso com ferruginizações (F igura 4e) semel hantes às do perfil da al ta vertente, mas sem continuidade no plasma, revela a al octonia deste material.

Analogamente, na meia vertente inferior, o perfil VDB3 apresenta o horizonte B espesso com feições pedológicas representadas por nódulos siltoargilosos, indicativas dealoctonia. Ambos os perfis da meia vertente apresentam os atributos diagnósticos necessários para serem considerados B latossólico (Bw). Entretanto, a identificação de elementos litorreliquiais demonstra que ainda há ligações evidentes com a rocha parental, portanto com feições intermediárias para $\mathrm{B}$ incipiente (Bi).

No segmento de baixa vertente o perfil de solo é pouco evoluído, com ausência de horizonte $B$, e desenvolve-se em ambiente redutor a partir de sedimentos aluviais depositados sobre o saprolito gnáissico. Observações microscópicas mostram a foliação gnáissica reliquial com a ocorrência incipiente de um plasma de composição, caulinita, gibbsita, goethita e sericita (Figura 4f).

Desta forma, a toposseqüência 1 tem o seu segmento de alta vertente representado por um perfil pouco desenvolvido, intensamente perturbado por veios intrusivos, numa zona de interflúvio sustentada por geomateriais muito resistentes ao intemperismo (quartzo e turmalinito), dificultando a formação de um perfil de solo homogêneo. Tais circunstâncias demonstram tratar-se de um local onde a erosão laminar é atualmente atuante (aumento da declividade), provocando o desmontee espal hamento dos fragmentos (nódulos) encontrados no perfil dealta vertente. As frações mais finas (silte e argila) são transportadas mais rapidamente vertente abaixo em direção ao segmento de meia vertente, deixando para trás as frações mais grosseiras (nódulos litorreliquiais e fragmentos de quartzo eturmalinito). Adicionalmente, a presença 
Quadro 1. Profundidade, cor, textura e características estruturais macroscópicas dos solos das toposseqüências investigadas

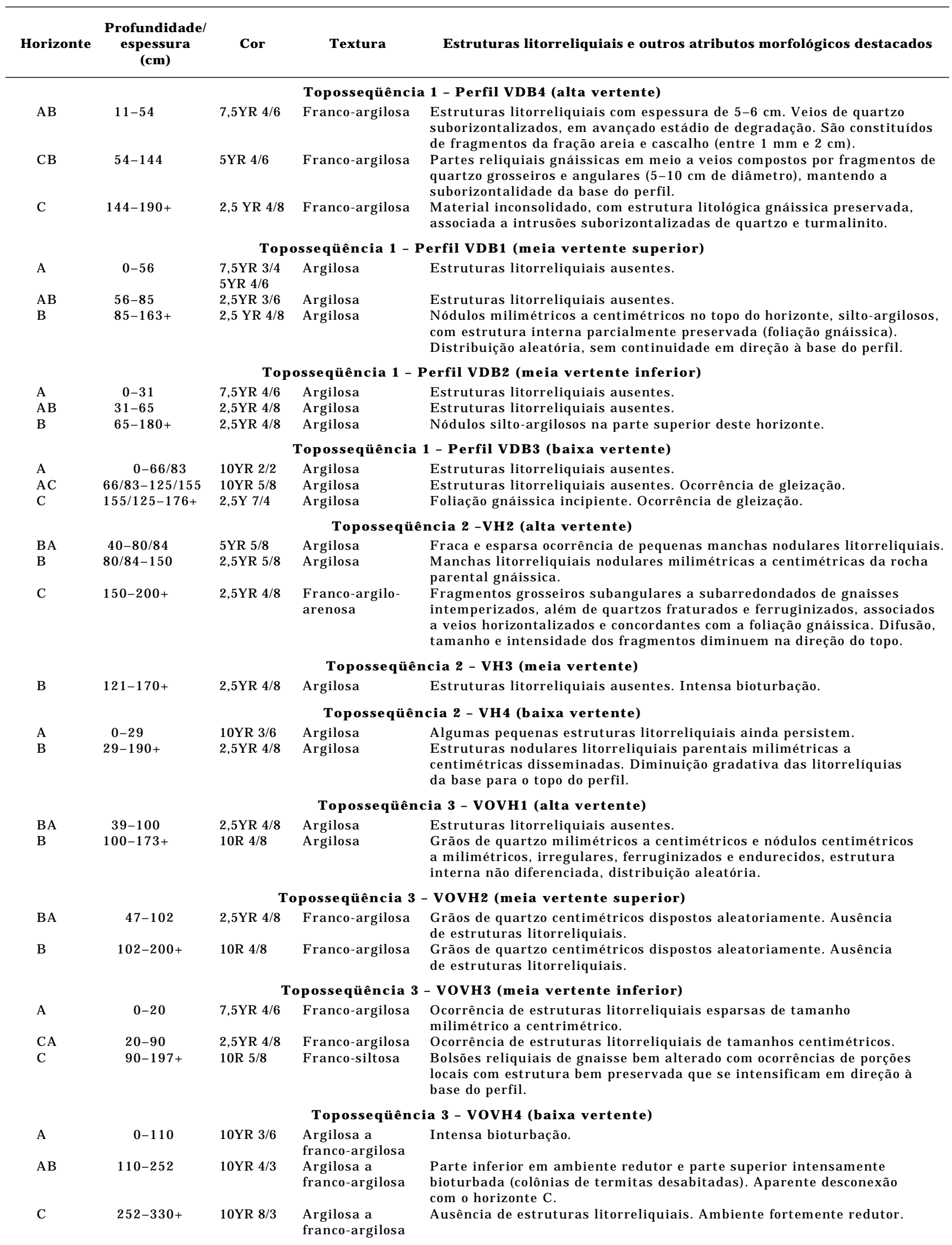


Quadro 2. Caracteres micromorfológicos dos horizontes subsuperficiais dos solos das toposseqüências investigadas

\begin{tabular}{|c|c|c|c|c|c|}
\hline \multirow{2}{*}{ Horizonte } & \multicolumn{5}{|c|}{ Matiz S } \\
\hline & Observação & Poros & E squeleto & Plasma & F eição pedológica \\
\hline \multicolumn{6}{|c|}{ Toposseqüência 1 - Perfil VDB4 (alta vertente) } \\
\hline $\mathrm{CB}$ & $\begin{array}{l}\text { Menor tamanho e } \\
\text { intensidade de } \\
\text { domínios com } \\
\text { estrutura } \\
\text { preservada em } \\
\text { relação à } \\
\text { superfície. }\end{array}$ & $\begin{array}{l}\text { Fendas e } \\
\text { cavidades } \\
\text { interconectadas } \\
\text { nos espaços } \\
\text { inter e intra- } \\
\text { agregados. }\end{array}$ & $\begin{array}{l}\text { Quartzoso }(\varnothing<1,95 \mathrm{~mm}) \\
\text { ocupando cerca de } 15 \% \\
\text { do fundo matricial. }\end{array}$ & $\begin{array}{l}\text { Argilo-ferruginoso, } \\
\text { fraca anisotropia, } \\
\text { estrutura } \\
\text { silassépica. }\end{array}$ & $\begin{array}{l}\text { Nódul os argilo-ferruginosos } \\
\text { (0,01 a } 0,21 \mathrm{~mm}) \text { e } \\
\text { pedotúbulos. }\end{array}$ \\
\hline C & $\begin{array}{l}\text { Domínios com } \\
\text { estrutura } \\
\text { conservada e forte } \\
\text { pseudomorfismo, à } \\
\text { exceção do } \\
\text { quartzo. Rede de } \\
\text { descontinuidades } \\
\text { dos fel dspatos } \\
\text { completamente } \\
\text { sericitizados e } \\
\text { caulinizados com } \\
\text { padrão de } \\
\text { alteração } \\
\text { pelicular. Micas } \\
\text { (biotitas) } \\
\text { totalmente } \\
\text { sericitizadas e } \\
\text { caulinizadas com } \\
\text { impregnações } \\
\text { ferruginosas pela } \\
\text { exsudação do ferro } \\
\text { dos seus retículos. }\end{array}$ & $\begin{array}{l}\text { Fendas e } \\
\text { cavidades } \\
\text { isoladas e } \\
\text { pouco } \\
\text { numerosas. }\end{array}$ & $\begin{array}{l}\text { Ocupa } 20 \% \text { do fundo } \\
\text { matricial, é constituído } \\
\text { majoritariamente de } \\
\text { grãos de quartzo de } \\
\text { tamanho e forma } \\
\text { variadas }(\varnothing<2,17 \mathrm{~mm}) \text {, } \\
\text { com impregnações } \\
\text { ferruginosas nas } \\
\text { fraturas e bordas em } \\
\text { continuidade com o } \\
\text { plasma. Localmente, } \\
\text { associam-se ao esquel eto } \\
\text { feldspatos } \\
\text { pseudomorfizados, } \\
\text { sericitas, turmalinas e } \\
\text { zircões. }\end{array}$ & $\begin{array}{l}\text { Pouco abundante, } \\
\text { ferruginizado, } \\
\text { isotrópico, de cor } \\
\text { bruno-avermel hada } \\
\text { e constituído } \\
\text { mineralogicamente } \\
\text { por caulinita, } \\
\text { gibbsita e sericita. }\end{array}$ & $\begin{array}{l}\text { Nódulos ferruginosos, } \\
\text { isótropos, maciços, com } \\
\text { tamanhos de } 0,01 \text { a } 0,21 \mathrm{~mm}, \\
\text { estrutura interna homogênea } \\
\text { e, alguns pedotúbulos. } \\
\text { Frequentes impregnações nas } \\
\text { fraturas e bordas dos cristais } \\
\text { de quartzo. }\end{array}$ \\
\hline \multicolumn{6}{|c|}{ Toposseqüência 1 - Perfil VDB 1 (meia vertente superior) } \\
\hline B & $\begin{array}{l}\text { Forma um padrão } \\
\text { porfirosquélico e } \\
\text { localmente } \\
\text { aglomeroplásmico. }\end{array}$ & $\begin{array}{l}\text { Fendas e } \\
\text { cavidades } \\
\text { inter- } \\
\text { agregadas } \\
\text { muito } \\
\text { numerosas e } \\
\text { fraturadas. }\end{array}$ & $\begin{array}{l}\text { Representam cerca de } \\
20 \% \text { do fundo matricial, } \\
\text { sendo majoritariamente } \\
\text { quartzoso }(\varnothing<1,23 \mathrm{~mm}), \\
\text { com palhetas de sericita. } \\
\text { Ferruginizações dos } \\
\text { grãos de quartzo nos } \\
\text { bordos e internamente } \\
\text { sem continuidade no } \\
\text { plasma (F igura } 4 \mathrm{e}) \text {. }\end{array}$ & $\begin{array}{l}\text { Abundante, argilo- } \\
\text { ferruginoso, } \\
\text { fracamente } \\
\text { anisótropo, com } \\
\text { estrutura } \\
\text { silassépica, cor } \\
\text { bruno-avermel hada, } \\
\text { mineralogicamente } \\
\text { constituído por } \\
\text { caulinita, gibbsita e } \\
\text { goethita } \\
\text { (Figura 4d). }\end{array}$ & $\begin{array}{l}\text { Glébulas de } 0,03 \mathrm{~mm} \text { a } \\
0,6 \mathrm{~mm} \text {, separadas em dois } \\
\text { grupos. O primeiro, nódul os } \\
\text { litorreliquiais (Figura 4c) } \\
\text { contendo arcabouço gnáissico } \\
\text { pseudomorfizado em caulinita } \\
\text { e, ou, sericita, envol vido por } \\
\text { halo argilo-ferruginoso no seu } \\
\text { interior. No segundo, nódul os } \\
\text { pedorreliquiais com estrutura } \\
\text { interna homogênea e } \\
\text { indiferenciada. }\end{array}$ \\
\hline $\begin{array}{l}\text { Nódulos da } \\
\text { parte } \\
\text { superior do } \\
\text { horizonte B }\end{array}$ & & $\begin{array}{l}\text { Fendas e } \\
\text { cavidades } \\
\text { muito } \\
\text { numerosas e } \\
\text { interconectadas. }\end{array}$ & $\begin{array}{l}\text { Ocupa cerca de } 15 \% \text { do } \\
\text { fundo matricial, } \\
\text { predominando quartzos } \\
\text { (Ø<2,70 mm) e } \\
\text { arcabouços pontuais de } \\
\text { gnaisse } \\
\text { pseudomorfizados mas } \\
\text { com resquícios da } \\
\text { foliação gnáissica } \\
\text { parcialmente } \\
\text { preservada. }\end{array}$ & $\begin{array}{l}\text { Argilo-ferruginoso } \\
\text { muito abundante, } \\
\text { ligeiramente } \\
\text { anisótropo com } \\
\text { estrutura } \\
\text { silassépica e } \\
\text { porfirosquélica. }\end{array}$ & $\begin{array}{l}\text { Ferruginizações nas fraturas } \\
\text { e bordas de dissol ução dos } \\
\text { grãos de quartzo em } \\
\text { continuidade com o } \\
\text { plasma. }\end{array}$ \\
\hline \multicolumn{6}{|c|}{ Toposseqüência 1 - Perfil VDB 2 (meia vertente inferior) } \\
\hline B & & $\begin{array}{l}\text { Fendas e } \\
\text { cavidades } \\
\text { interagregadas } \\
\text { muito } \\
\text { numerosas e } \\
\text { fraturadas. }\end{array}$ & $\begin{array}{l}\text { Ocupa cerca de } 18 \% \text {, } \\
\text { quartzoso }(\varnothing<1,79 \mathrm{~mm}) \text {, } \\
\text { com fragmentos pontuais } \\
\text { de fel dspatos } \\
\text { pseudomorfizados, } \\
\text { caracterizando um } \\
\text { padrão porfirosquélico. }\end{array}$ & $\begin{array}{l}\text { Argilo-ferruginoso, } \\
\text { com ligeira } \\
\text { anisotropia e } \\
\text { estrutura } \\
\text { silassépica. }\end{array}$ & $\begin{array}{l}\text { Nódulos litorreliquiais } \\
\text { dispersos, de tamanhos } \\
\text { milimétricos. F eições } \\
\text { ferruginizadas esqueletais } \\
\text { abruptamente interrompidas } \\
\text { no contato com o plasma. }\end{array}$ \\
\hline
\end{tabular}


Quadro 2, Continuação

\begin{tabular}{|c|c|}
\hline Horizonte & Observação \\
\hline C & $\begin{array}{l}\text { F oliação gnáissica } \\
\text { reliquial com } \\
\text { intercalação de } \\
\text { bandas com } \\
\text { constituintes } \\
\text { micáceos (sericita), } \\
\text { textura } \\
\text { lepidoblástica, com } \\
\text { bandas quartzosas e } \\
\text { feldspatos } \\
\text { pseudomorfizados, } \\
\text { caracterizando uma } \\
\text { textura } \\
\text { granolepidoblástica } \\
\text { com padrão } \\
\text { aglomeroplásmico e } \\
\text { porfirosquélico. }\end{array}$ \\
\hline
\end{tabular}

Toposseqüência 2 - Perfil VH 2 (alta vertente)

B Domínios do tipo porfirosquélico.
Fendas e cavidades abundantes.

\author{
Quartzoso $(\varnothing<1$, \\ $53 \mathrm{~mm})$, com partículas \\ subangulosas a \\ subarredondadas, \\ ocupando cerca de $50 \%$ \\ do fundo matricial
}

Quartzoso, com litorrelíquias de feldspatos com borda ferruginosa, finas palhetas de sericitas. Há predomínio de grãos subangulosos a subarredondados.
Argilo-ferruginoso, com baixa anisotropia e estrutura silassépica, muito abundante, constituído por caulinita, gibbsita, goethita e traços de sericita.

Incipiente, argiloferruginoso formado por gibbsita, goethita, caulinita predominante. Os domínios são dos tipos aglomeroplásmicos e granulares.

Domínios aglomeroplásmicos.

Plasma argiloporfirosquélicos e
Toposseqüência 2 - Perfil VH 3 (meia vertente) Fendas e Quartzoso $(\varnothing<0$ cavidades numerosas. ferruginoso anisótropo
Quartzoso $(\varnothing<0$,
$59 \mathrm{~mm})$, subangulos subarredondado, ocupando cerca de $18 \%$ do fundo matricial. abundante com estrutura silassépica mineralógicamente constituído por caulinita, gibbsita e goethita

Toposseqüência 2 - Perfil VH4 (baixa vertente)

\section{F endas e cavidades isoladas e \\ pouco} reliquial com intercalação de bandas quartzosas e feldspatos pseudomorfizados com bandas mais micáceas. aglomeroplásmicos. numerosas.

\author{
Ocupa $20 \%$ do fundo \\ matricial, é constituído \\ majoritariamente de \\ grãos de quartzo de \\ tamanho e forma \\ variadas.
}

Incipiente ferruginizado isotrópico, constituído mineralógicamente por caulinita, gibbsita e sericita.

\section{Toposseqüência 3 - Perfil voVH 1 (alta vertente)}

F endas e cavidades abundantes.
Ferruginizações nas bordas das litorrelíquias de feldspatos e nas fraturas e cavidades esqueletais quartzosas em continuidade com o plasma. Marcante aumento de litorrelíquias no sentido topo-base.

Ferruginizações localizadas principalmente nas bordas do arcabouço gnáissico e nas descontinuidades inter e intra-grãos.
F erruginizações nas fraturas e cavidades do esqueleto quartzoso que são abruptamente interrompidas no contato com o plasma.
Quartzoso $(\varnothing<138 \mathrm{~mm})$,

subangulosos a

subarredondados,

ocupando cerca de $20 \%$ do fundo matricial.
Argilo-ferruginoso anisótropo silassépico, muito abundante de composição caulinítica, goethítica e gibsítica

(Figura 6b)
I mpregnações ferruginosas nos planos de xistosidade dos minerais micáceos.

I mpregnações ferruginosas nas fraturas e bordas em continuidade com o plasma incipiente.
Nódulos argilo-ferruginosos $(\varnothing<0,10 \mathrm{~mm})$ abundantes, desorganizados, em contato nítido com o plasma

(Figura 6a). F erruginizações dos quartzos nas bordas, fraturas e cavidades em contato abrupto com o plasma. 
Quadro 2, Continuação

\begin{tabular}{|c|c|c|c|c|c|}
\hline \multirow{2}{*}{ Horizonte } & \multicolumn{5}{|c|}{ Matiz S } \\
\hline & Observação & Poros & Esqueleto & Plasma & Feição pedológica \\
\hline \multicolumn{6}{|c|}{ Toposseqüência 3 - Perfil VOVH2 (meia vertente superior) } \\
\hline B & $\begin{array}{l}\text { Domínios } \\
\text { porfirosquélicos e } \\
\text { aglomeroplásmicos. }\end{array}$ & $\begin{array}{l}\text { Fendas e } \\
\text { cavidades } \\
\text { abundantes. }\end{array}$ & $\begin{array}{l}\text { Quartzoso ( } \varnothing<0 \text {, } \\
375 \mathrm{~mm} \text { ), subangulosos a } \\
\text { subarredondados. } \\
\text { compreendendo cerca de } \\
20 \% \text { do fundo matricial. }\end{array}$ & $\begin{array}{l}\text { Argilo-ferruginoso, } \\
\text { silassépico } \\
\text { abundante de } \\
\text { composição } \\
\text { caulinítica e } \\
\text { gibsítica } \\
\text { (Figura 6d). }\end{array}$ & $\begin{array}{l}\text { Nódulos argilo-ferruginosos } \\
\text { ( } \varnothing<0,035 \mathrm{~mm} \text { ), pouco } \\
\text { abundantes. I mpregnações } \\
\text { ferruginosas envolvendo o } \\
\text { esquel eto quartzoso em pontos } \\
\text { específicos sem continuidade } \\
\text { com o plasma. }\end{array}$ \\
\hline \multicolumn{6}{|c|}{ Toposseqüência 3 - Perfil VOVH3 (meia vertente inferior) } \\
\hline $\mathrm{C}$ & $\begin{array}{l}\text { Domínios com } \\
\text { preservação da } \\
\text { estrutura. } \\
\text { Feldspatos total e, } \\
\text { ou, parcialmente } \\
\text { pseudomorfizados } \\
\text { em domínio } \\
\text { granular. }\end{array}$ & n.o. & $\begin{array}{l}\text { Quartzoso, com } \\
\text { abundantes } \\
\text { litorrelíquias de } \\
\text { feldspatos com borda de } \\
\text { dissolução ferruginosa, } \\
\text { palhetas de sericitas e } \\
\text { zircão. Grãos } \\
\text { subangulosos a } \\
\text { subarredondados. }\end{array}$ & $\begin{array}{l}\text { Argilo-ferruginoso } \\
\text { incipiente, } \\
\text { composto por } \\
\text { gibbsita, goethita, } \\
\text { caulinita e sericita. }\end{array}$ & $\begin{array}{l}\text { Nódulos ferruginosos } \\
\text { ( } \varnothing<0,20 \mathrm{~mm} \text { ). Micas } \\
\text { pseudomorfizadas, com } \\
\text { impregnações ferruginosas } \\
\text { (F igura 6e) nos bordos e nos } \\
\text { planos de clivagem. }\end{array}$ \\
\hline \multicolumn{6}{|c|}{ Toposseqüência 3 - Perfil VOVH4 (baixa vertente) } \\
\hline $\mathrm{C}$ & $\begin{array}{l}\text { Desferruginizado } \\
\text { com raras } \\
\text { muscovitas } \\
\text { preservadas. } \\
\text { Intercalações } \\
\text { granulares } \\
\text { quartzosas, além } \\
\text { de feldspatos e } \\
\text { micas } \\
\text { pseudomorfizadas. } \\
\text { Foliação gnáissica } \\
\text { reliquial. }\end{array}$ & n.o. & $\begin{array}{l}\text { Quartzoso, segundo um } \\
\text { padrão porfirosquélico. }\end{array}$ & $\begin{array}{l}\text { F eições reliquiais } \\
\text { difusas no topo, } \\
\text { substituídas por um } \\
\text { plasma } \\
\text { esbranquiçado, } \\
\text { silassépico, de } \\
\text { composição } \\
\text { caulinítica. }\end{array}$ & $\begin{array}{l}\text { Ferruginizações esparsas e } \\
\text { pontuais. }\end{array}$ \\
\hline
\end{tabular}

n.o. = não observado

localizada de nódulos litorreliquiais no horizonte B da meia vertente e as ferruginizações esqueletais interrompidas evidenciam o caráter alóctone de pelo menos parte destes horizontes. Como fonte destes materiais, a zona de alta vertente seria a mais provável.

Do segmento de meia vertente para jusante, observa-se um comportamento pedogeomorfológico distinto, evidenciado pela ruptura de declive onde afloramentos de gnaisse funcionam como um anteparo, sustentando a zona de coluvionamento e interrompendo o fluxo de sedimentos coluviais provindos do transporte gravitacional e hídrico dos segmentos a montante. Ou seja, no segmento de meia vertente, processa-se um acúmulo de sedimentos, proporcionando condições favoráveis ao aprofundamento e intensificação do intemperismo químico, responsável pela formação dos perfis latossólicos ali verificados. A jusante do afloramento gnáissico, as características superficiais são compostas de sedimentos grosseiros (fração cascalho), cuja granulometria vai diminuindo gradativamente em direção ao segmento de baixa vertente.

O perfil dosegmento debaixa vertenteapresenta marcante diferenciação em relação aos perfis de montante. Desenvolve-se a partir de material aluvial depositado sobre o saprolito gnáissico deferruginizado, caracterizando um ambiente de saturação hídrica com acúmulo de matéria orgânica nas camadas superficiais eausência de horizonte $B$. O local amostrado indica uma zona de forte influência do ambientefluvial, sem qual quer indício de materiais de natureza coluvial, encontrando-se desenvolvido sobre um terraço (paleoplanície fluvial), que sobrepõe o saprolito gnáissico, caracterizando a incisão do Ribei rão Maracujá.

A distribuição dos el ementos maiores (Quadro 3) corrobora estes resultados, destacando-se maior concentração de $\mathrm{SiO}_{2} \mathrm{eK}_{2} \mathrm{O}$ no saprol ito do segmento de baixa vertente e uma deferruginização característica do seu perfil glei, onde teores mais baixos de $\mathrm{Fe}_{2} \mathrm{O}_{3}$ são encontrados.

\section{Toposseqüência 2 (VH)}

A toposseqüência 2 (Figuras 2 e $3 b$ ) corresponde a uma vertente de perfil longitudinal convexocôncavo-convexo, com declividades variando de 30$35 \%$ no terço superior, $15-30 \%$ no terço médio e inferior. $O$ extrato vegetacional corresponde a cerrado degradado com fisionomias de campo limpo 

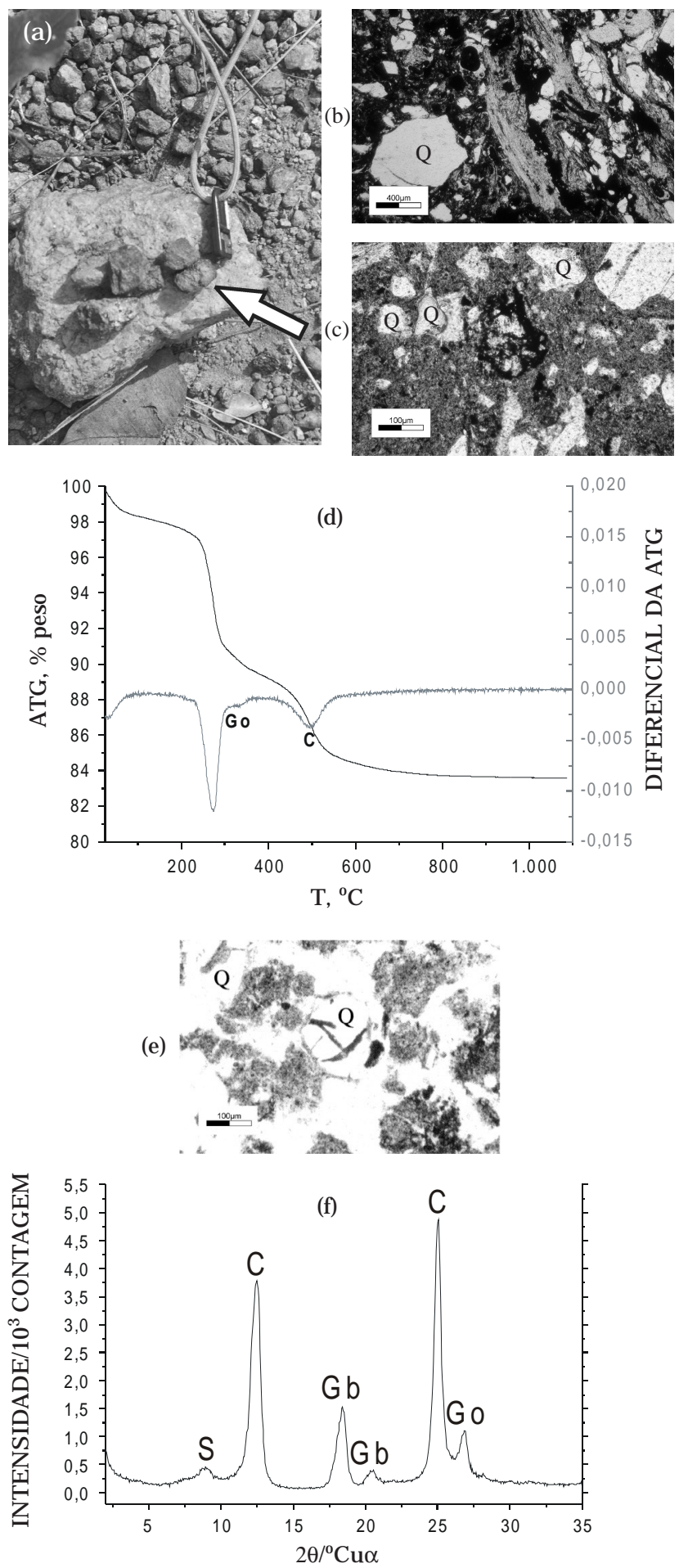

Figura 4. Aspectos micromorfológicos e mineralógicos da toposseqüência 1. (a) = fotografia da cobertura superficial da alta vertente (VDB4). (b) = fotomicrografia em luz polarizada do horizonte C de VDB4. (c) = fotomicrografia em luz plana do horizonte B de VDB1. (d) = ATG e sua derivada do horizonte $B$ de VDB1. (e) = Fotomicrografia em luz plana do horizonte B de VDB1. (f) = DRX do horizonte C de VDB3. $\mathbf{S}=$ sericita, $\mathbf{C}=$ caulinita, $\mathbf{G b}=$ gibbsita, $\mathbf{G o}=$ goethita, $Q$ = quartzo. e campo cerrado associado a Brachiaria brizantha nas pastagens plantadas. A cobertura superficial vai de não-pedregosa na alta vertentea ligeiramente pedregosa na meia vertentee na baixa vertente. Os perfis de solos ocorrentes nesta toposseqüência apresentam o horizonte B com variadas espessuras e diferentes graus de evolução. Na alta vertente, o horizonte $\mathrm{B}$ é inci piente e aponta para um perfil de natureza câmbica. Na meia vertente, o horizonte $\mathrm{B}$ é profundo, apresenta granulometria argilosa e pouca ocorrência de fragmentos de quartzo. Na baixa vertente, o perfil é parcialmente desenvolvido (Latossolo Câmbico), com forte ocorrência de feições granulares litorreliquiais, distribuídas por todo o perfil.

Esta toposseqüência é representada por três perfis pedológicos ( $\mathrm{VH} 2+\mathrm{VH} 3+\mathrm{VH} 4)$ aujas descrições macroscópicas e microscópicas encontram-se nos quadros 1 e 2, respectivamente. O Perfil de alta vertente (VH2) apresenta um horizonte $\mathrm{C}$ saprolítico que, gradualmente, passa para um horizonte $B$ incipiente com estruturas parentais (foliação) do embasamento gnáissico ainda identificáveis macroscopicamente. Microscopicamente, este horizonte C (Figura 5a), à semelhança do perfil da alta vertente da toposseqüência 1 , mostra litorrelíquias gnáissicas em associação com o esquel eto quartzoso com ferrugi nizações nas bordas e nos espaços intergrãos e com um plasma incipiente, argilo-ferruginoso, mineral ogicamente composto por caulinita, gibbsita, goethita, com traços de sericita (F igura 5b). No segmento de meia vertente, o perfil (VH3) é bastante desenvolvido, apresentando o horizonte B uma estruturação bastante uniforme, dificultando a identificação macroscópica de qualquer resquício de estruturas parentais. Micromorfol ogicamente, o horizonte B (Figura 5c), à semel hança do mesmo horizonte da média vertente da toposequência 1, apresenta um esquel eto quartzoso com ferruginizações em contato abrupto com o plasma composto de caulinita, gibbsita e goethita (Figura $5 \mathrm{~d}$ ), revelando aloctonia do material. No perfil da baixa vertente (VH4), são identificadas macro e mi croscopicamente estruturas litorreliquiais pseudomorfizadas distribuídas de forma decrescente no perfil no sentido base superfície, atestando sua natureza autóctone. Microscopicamente, o horizonte B (Figura 5e) apresenta um plasma argilo-ferruginoso de composição caulinítica e gibsítica (Figura 5f), envolvendo o esquel eto quartzoso.

O contato do segmento de baixa vertente com a incipiente planície fluvial se dá numa ruptura de declive (Figura $3 b$ ) e não de forma gradacional, de acordo com os model os geomorfológi cos tradicionais de evolução de vertentes (Carson \& Kirkby, 1972; Young, 1972, Ollier \& Pain, 1996).

Analogamente à toposseqüência 1, a distribuição dos el ementos maiores (Quadro 3) corrobora as 
Quadro 3. Resultados granulométricos e químicos de materiais de horizontes selecionados das toposseqüências investigadas. T1 = toposseqüência 1; T2 = toposseqüência 2; T3 = toposseqüência 3

\begin{tabular}{|c|c|c|c|c|c|c|c|c|c|c|c|}
\hline \multirow{2}{*}{ Toposseqüência } & \multirow{2}{*}{ Amostra } & \multirow{2}{*}{ Profundidade } & \multicolumn{3}{|c|}{ Granulometria } & \multirow{2}{*}{ Textura } & \multirow{2}{*}{$\mathrm{SiO}_{2}$} & \multirow{2}{*}{$\mathrm{Al}_{2} \mathrm{O}_{3}$} & \multirow{2}{*}{$\mathrm{Fe}_{2} \mathrm{O}_{3}$} & \multirow{2}{*}{$\mathrm{K}_{2} \mathrm{O}$} & \multirow{2}{*}{$\mathrm{TiO}_{2}$} \\
\hline & & & Argila & Silte & Areia & & & & & & \\
\hline & & $\mathrm{cm}$ & 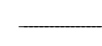 & $-\%$ & - & & & & $\%$ & & \\
\hline $\mathrm{T} 1$ & $\begin{array}{l}\text { AV C } \\
\text { MVsB } \\
M V i B \\
B \vee C\end{array}$ & $\begin{array}{l}170 \\
130 \\
130 \\
160\end{array}$ & $\begin{array}{l}29,1 \\
48,9 \\
48,9 \\
54,4\end{array}$ & $\begin{array}{l}49,6 \\
26,9 \\
26,96 \\
15,40\end{array}$ & $\begin{array}{l}21,3 \\
24,1 \\
24,11 \\
30,18\end{array}$ & $\begin{array}{l}\text { Franco-argilosa } \\
\text { Argilosa } \\
\text { Argilosa } \\
\text { Argilosa }\end{array}$ & $\begin{array}{l}\text { n.a. } \\
39,10 \\
46,50 \\
67,20\end{array}$ & $\begin{array}{l}\text { n.a. } \\
32,80 \\
34,50 \\
27,30\end{array}$ & $\begin{array}{l}\text { n.a. } \\
8,27 \\
3,94 \\
1,15\end{array}$ & $\begin{array}{l}\text { n.a. } \\
0,24 \\
0,21 \\
1,29\end{array}$ & $\begin{array}{l}\text { n.a. } \\
0,90 \\
0,47 \\
0,82\end{array}$ \\
\hline $\mathrm{T} 2$ & $\begin{array}{l}\text { AV B } \\
\text { AV C } \\
\text { MV B } \\
\text { BV B } \\
\text { BV C }\end{array}$ & $\begin{array}{l}115 \\
180 \\
145 \\
130 \\
500\end{array}$ & $\begin{array}{r}40,9 \\
30,0 \\
63,1 \\
48,7 \\
7,5\end{array}$ & $\begin{array}{l}26,20 \\
23,60 \\
12,28 \\
20,93 \\
66,12\end{array}$ & $\begin{array}{l}32,83 \\
46,35 \\
24,56 \\
30,37 \\
26,37\end{array}$ & $\begin{array}{l}\text { Argilosa } \\
\text { Franco-argilo-arenosa } \\
\text { Argilosa } \\
\text { Argilosa } \\
\text { Franco-siltosa }\end{array}$ & $\begin{array}{l}39,60 \\
43,80 \\
33,70 \\
46,40 \\
63,90\end{array}$ & $\begin{array}{l}33,00 \\
32,40 \\
33,00 \\
30,30 \\
28,50\end{array}$ & $\begin{array}{l}4,52 \\
3,88 \\
5,73 \\
4,05 \\
2,08\end{array}$ & $\begin{array}{l}0,28 \\
0,57 \\
0,10 \\
0,22 \\
0,49\end{array}$ & $\begin{array}{l}0,60 \\
0,49 \\
0,79 \\
0,72 \\
0,58\end{array}$ \\
\hline T3 & $\begin{array}{l}\text { AV B } \\
\text { MVs B } \\
\text { MViC } \\
\text { BV C }\end{array}$ & $\begin{array}{l}140 \\
150 \\
160 \\
290\end{array}$ & $\begin{array}{l}54,5 \\
38,7 \\
18,8 \\
42,8\end{array}$ & $\begin{array}{l}17,06 \\
27,62 \\
52,29 \\
23,11\end{array}$ & $\begin{array}{l}28,46 \\
33,66 \\
28,85 \\
34,06\end{array}$ & $\begin{array}{l}\text { Argilosa } \\
\text { Franco-argilosa } \\
\text { Franco-siltosa } \\
\text { Argilosa }\end{array}$ & $\begin{array}{l}50,40 \\
38,40 \\
62,80 \\
59,80\end{array}$ & $\begin{array}{l}26,70 \\
35,10 \\
29,90 \\
34,30\end{array}$ & $\begin{array}{l}5,68 \\
2,13 \\
4,00 \\
1,15\end{array}$ & $\begin{array}{l}0,42 \\
0,42 \\
1,18 \\
0,47\end{array}$ & $\begin{array}{l}0,89 \\
0,72 \\
0,49 \\
0,48\end{array}$ \\
\hline
\end{tabular}

$\mathrm{AV}=$ alta vertente; $\mathrm{MV}=$ meia vertente; $\mathrm{MVs}=$ meia vertente superior; $\mathrm{MVi}=$ meia vertente inferior; $\mathrm{BV}=$ baixa vertente; $\mathrm{B}=$ horizonte $\mathrm{B}$; $\mathrm{C}=$ horizonte $\mathrm{C}$; n.a. = não analisado.

(a)

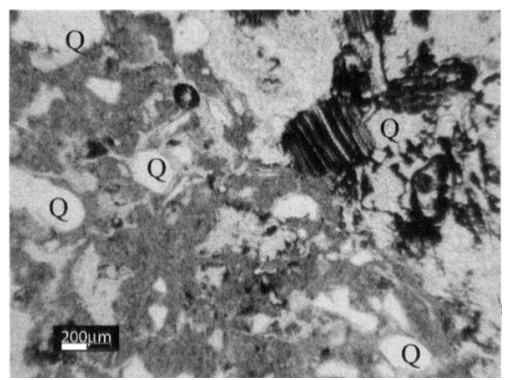

(c)

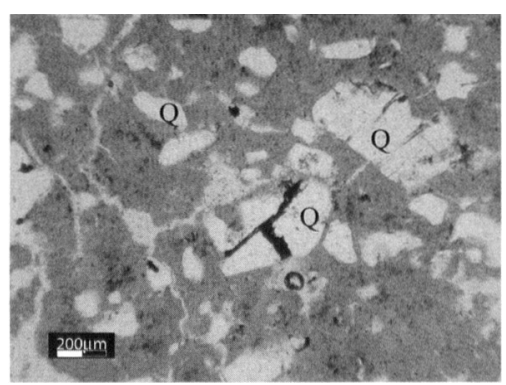

(e)

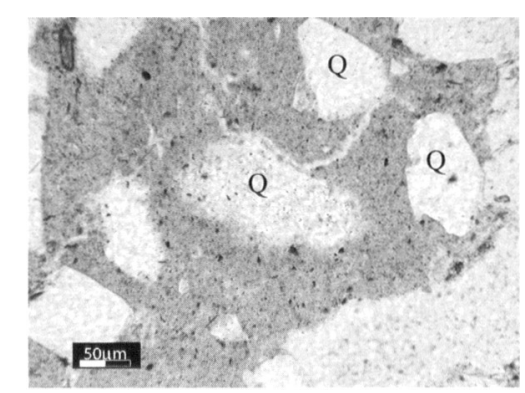

(b)
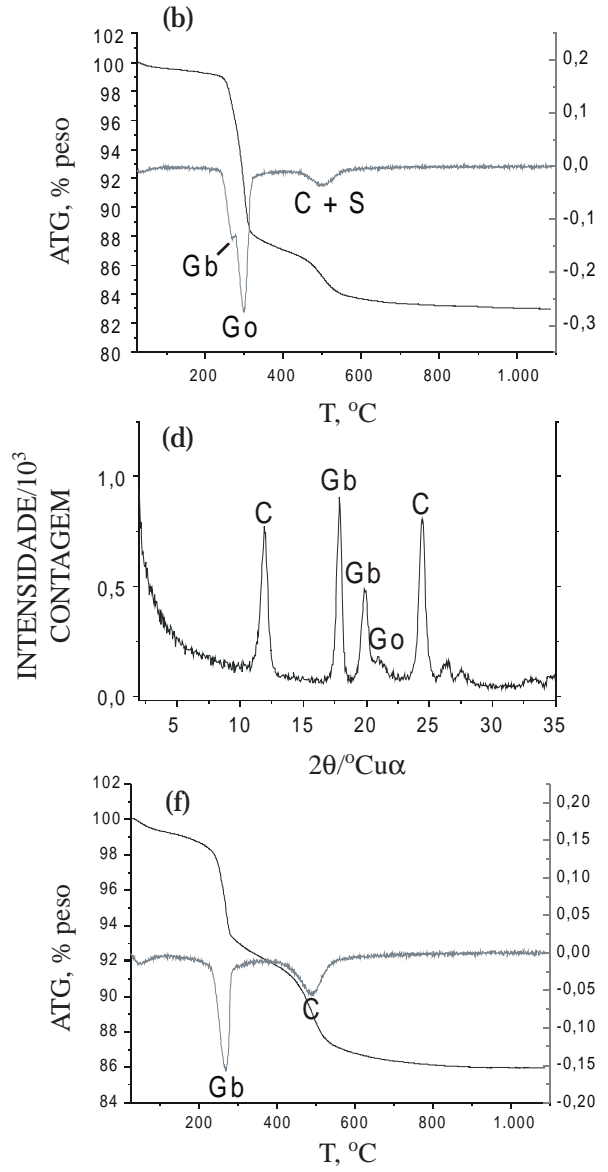

Figura 5. Aspectos micromorfológi cos e mineralógicos da toposseqüência 2. (a) =F otomicrografia em luz plana do horizonte $\mathrm{C}$ de VH2. (b) =ATG e sua derivada, mostrando a composição do plasma inci piente do horizonte C de VH2. (c) = Fotomicrografia em luz plana do horizonte B de VH3, mostrando o esqueleto quartzoso (Q) com ferruginização em contato abrupto com o plasma. (d) = DRX do horizonte B de VH3. (e) = F otomicrografia em luz polarizada do horizonte B de VH4, (Q) = esqueleto quartzoso. (f) =ATG e sua derivada do horizonte B de Vh4. C = caulinita, Gb = gibbsita, Go = goethita, $\mathbf{S}=$ sericita. 
evidências micromorfológicas, ocorrendo uma maior concentração de $\mathrm{SiO}_{2}$ e $\mathrm{K}_{2} \mathrm{O}$ nos horizontes saprolíticos e depleção de ferro na baixa vertente. Desta forma, similarmente à toposseqüência 1 supracitada, conclui-se que os perfis de alta e baixa vertente assumem um processo evolutivo semel hantee distinto do perfil de meia vertente. Os perfis de alta vertente e baixa vertente são caracterizados como autóctones el uviais (Cambissolo e Latossolo Câmbico, respectivamente), evidenciados pela clara relação gradacional decrescente, no sentido base topo, de estruturas litorreliquiais. A ausência de qual quer resquício de organização e de relação gradacional com o horizonte $C$ evidencia o caráter alóctone coluvial do perfil de meia vertente.

\section{Toposseqüência 3}

A toposseqüência 3 (Figura $3 c$ ) corresponde a uma vertente de perfil longitudinal convexo, com declividades variando de $15 \%$ no terço superior e médio a 40-45\% no terço inferior. O extrato vegetacional corresponde a cerradão subperenifólio (mata) na alta vertente, seguido de espécies gramíneas, herbáceas e arbustivas naturais (campo cerrado) no segmento de meia vertente superior; gramíneas e herbáceas rasteiras na meia vertente inferior (aumento da declividade) e vegetação gramínea e herbácea densa no segmento de baixa vertente. A cobertura superficial vai de nãopedregosa na al ta vertentea ligei ramente pedregosa na meia vertente e na baixa vertente. Os perfis de sol os ocorrentes são bem desenvolvidos (horizonte $B$ profundo) e argilosos na alta vertente e, na meia vertente, transicionam para um pedoambiente litólico (neossol olitólico), com granul ometria francoargil osa a franco-siltosa. Na baixa vertente, o sol o é pouco desenvolvido (ausência de horizonte B), argiloso, apresentando forte desferruginização dos horizontes de subsuperfície e feições da atividade fluvial pretérita.

Esta toposseqüência é representada por quatro perfis pedológicos (VOVH $1+$ VOVH2 + VOVH3 + VOVH4), cuja descrição macroscópica (Quadro 1), acompanhada da descrição micromorfológica (Quadro 2), mostra a mesma ruptura evolutiva evidenciada nas toposseqüências 1 e 2 . O perfil de alta vertente (VOVH 1) apresenta características de maturidade pedológica, manifestada pela espessura (aproximadamente $3 \mathrm{~m}$, diagnosticada por tradagem) e uniformização estrutural macroscópica do horizonte $B$. Micromorfologicamente, este horizonte B (Figura 6a) é representado por um plasma argilo-ferruginoso constituído de caulinita, gibbsita e goethita (Figura $6 \mathrm{~b}$ ) envolvendo um esquel eto quartzoso e nódulos pedorreliquiais. O segmento de meia vertente superior (VOVH2) apresenta feições macro e micromorfológicas (Figura 6c) similares às do perfil anterior, apresentando o horizonte B um plasma argiloferruginoso caulinítico e gibbsítico (Figura $6 \mathrm{~d}$ ), um esquel eto quartzoso com impregnações ferrugi nosas abruptamente interrompidas no contato com o plasma e nódul os pedorreliquiais. Adicionalmente, no talude da cabeceira da voçoroca situada neste mesmo segmento, constata-se a ocorrência de uma stoneline na transição entre o horizonte $B$ e o horizonte $\mathrm{C}$.

A partir do segmento de meia vertente, inicia-se uma descontinuidade evol utiva, ocorrendo no perfil de meia vertenteinferior (VOVH3) um pedoambiente imaturo, com as características parentais, macro e micromorfol ogicamente, ainda bastantepronunciadas. Nohorizonte C (F igura 6e), os fragmentos de gnaisse encontram-se intensamente pseudomorfizados e com impregnações ferruginosas. A composição mineralógica deste fundo matricial (Figura 6f) é representada predominantemente por caulinita, gibbsita e, secundariamente, por goethita.

No perfil de baixa vertente (VOVH4), observa-se um pedoambientetambém pouco desenvol vido, onde a influência fluvial é evidente. O local escolhido representa uma ruptura topográfica entre a baixa vertente e a planíciefluvial do Córrego da Holanda. O horizonte $\mathrm{C}$ desferruginizado e de natureza flúvica mostra um paleonível piezométrico, cujos indícios podem ser percebidos pela continuidade lateral da referida zona, sobreposto por horizontes intensamente bioturbados. Não há horizonte $\mathrm{B}$ característico de ambiente de acumulação sob condições de boa drenagem.

Portanto, a toposseqüência 3 apresenta al gumas características distintas das toposseqüências 1 e 2 . O Perfil de alta vertente da toposseqüência 3 diferencia-se dos perfis do mesmo segmento nas toposseqüências 1 e 2 por ser constituído de material alóctone. Esta constatação é confirmada pela correlação das suas feições micromorfológicas com as dos perfis de meia vertente das toposequências 1 e 2, além da evidente maturidade pedológica.

Nesse sentido, é importante ressaltar que o relacionamento das formas de relevo - ou simplesmente da paisagem geomorfológica - com a pedogênese inclui componentes tanto dinâmicos quanto estáticos, resultantes da interação de processos (erosão, soerguimento, etc.) com materiais (sol os e rochas) que recobrem a parte mais el evada da crosta terrestre (Segovia \& Foss, 1984). I nversamente, a paisagem, em parte determina as bases que controlam as taxas (intensidade da ação) de processos pedogênicos. Dentre os fatores que constam nestas bases deter minantes estão (Segovia \& Foss, 1984): natureza do material parental ou sedimentos subjacentes, topografia, idade, hidrol ogia subsuperficial, estrutura geológica e tectonismo, el evação, exposição e clima; não sendo estes fatores necessariamente independentes.

As paisagens representam uma síntese visível de muitos dos mesmos fatores e processos responsáveis pela formação dos solos, cuja interpretação é uma 
(a)

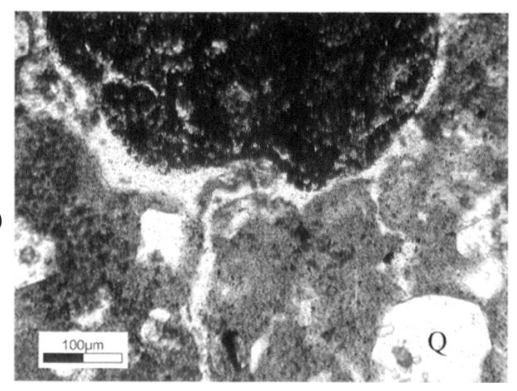

(c)

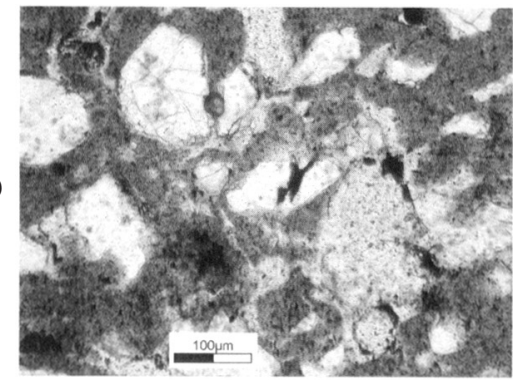

(e)

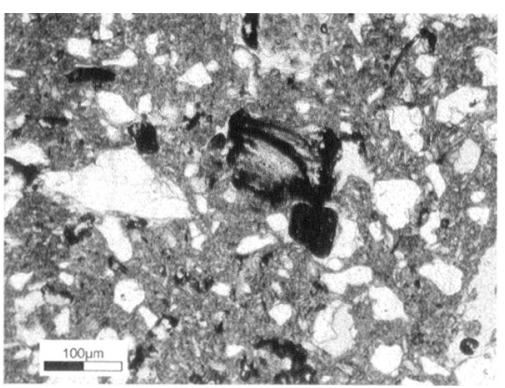

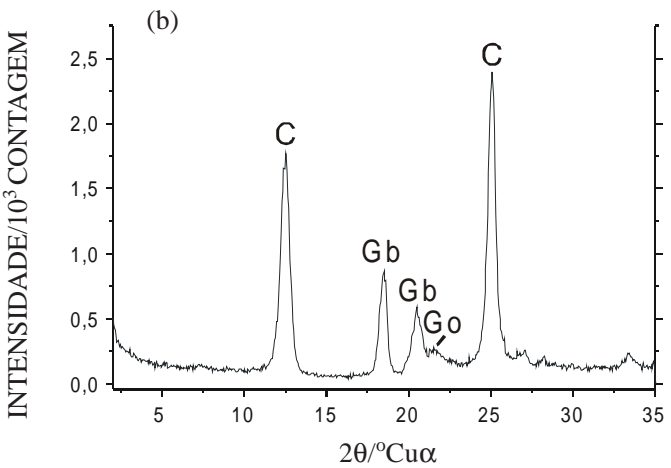
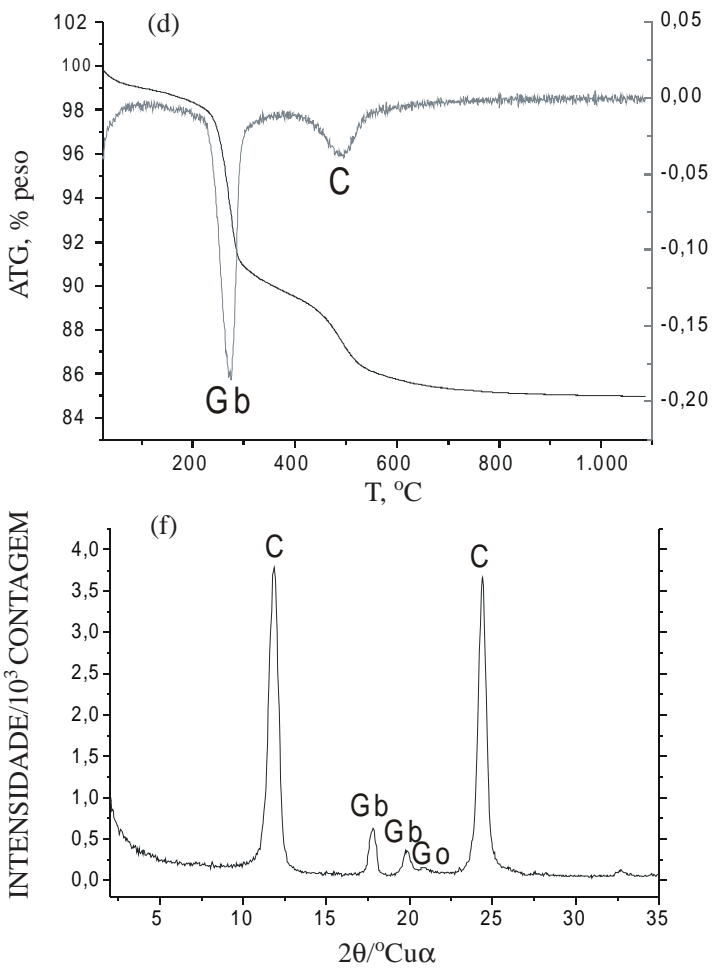

Figura 6. Aspectos micromorfológicos e mineralógicos da toposseqüência 3. (a) =Fotomicrografia em luz plana do horizonte B de VOVH1. (b) = DRX do horizonte B de VOVH1. (c) = Fotomicrografia em luz plana do horizonte B de VOVH2. (d) = ATG e sua derivada do horizonte B de VOVH2. (e) = Fotomicrografia em luz polarizada do horizonte C de VOVH3. (f) = DRX do horizonte C de VOVH3. C = caulinita, $\mathbf{G b}=$ gi bbsita, $\mathbf{G o}=$ goethita.

ferramenta muito utilizada em outros países em serviços de levantamento eaval iação de solos, razão pela qual deveria preceder seus estudos. Reciprocamente, uma investigação pedológica de sol os atuais, ou pal eossolos, também é extremamente útil no entendimento do desenvolvimento das paisagens (Segovia \& F oss, 1984). Com o exposto, o presente trabalho apresenta alguns componentes principais que referendam o raciocínio acima, pois procura estabelecer a relação existente entre as características atuais da paisagem local ea dinâmica pedoambiental.

Ollier \& Pain (1996) relatam que, em alguns mapas e relatórios de levantamentos de solos e de pedossistemas, falta aos autores uma compreensão de princípios geomórficos. Não se trata de simplesmente descrever em detalhes as formas de relevo, embora isto seja importante. Quem mapeia o regol ito (zona de alteração compreendida desde a rocha sã atéà superfície, incluindo-se aí o solo) e as formas de relevo também tem de compreender princípios geomórficos básicos (flutuações paleodimáticas, tectonismo, etc.) que suportam a explicação da evolução das formas de relevo e o desenvolvimento do regolito. Essas idéias incluem evolução dos padrões de drenagem, processos e evolução de vertentes, processos fluviais e o desenvolvimento de planícies fluviais, terraços e leques aluviais, além de teorias de mudanças das formas de relevo a longo prazo. A evolução de regolito está intimamente ligada à evolução das formas de relevo (paisagem) nas quais os princípios geomórficos devem ser considerados. 
Segundo Ollier \& Pain (1996), uma completa compreensão da distribuição de regolito em determinada área apenas torna-se possível com o desenvol vimento de um model o de formas de rel evo e evolução de regol ito. Tal model o deveestar baseado em firmes princípios geomórficos etem de responder pela distribuição da paisagem e dos sol os na área de estudo. Os modelos propostos (Carson \& Kirkby, 1972; Young, 1972, Ollier \& Pain, 1996) apontam para um sistema em que as vertentes podem ser divididas em vários segmentos, de acordo com sua extensão linear. A evol ução das vertentes dar-se-ia através deerosão regressiva, diminuindo progressivamentesua indinaçãoe, ao mesmotempo, promovendo a denudação (rebaixamento) da paisagem. Aolongo do processo de denudação, ocorreriam vários ciclos pedogenéticos, alternando-se principalmente de acordo com as flutuações climáticas, além de soerguimentos lentos e localizados.

Os materiais intemperizados produzidos na alta vertente tenderiam a uma contínua movimentação lateral para jusante, tendo como agentes de transporte a gravidade e a percolação hídrica, mantendo o front de intemperismo da alta vertente em constante mutação. Isso proporcionaria um pedoambiente permanentemente imaturo (Neossolos Litólicos, Cambissolos, etc.). Os segmentos de meia e baixa vertente seriam uma zona de acumulação (coluvionamento) e na baixa vertente haveria, dadas as condições necessárias em termos de tempo, permeabilidade hídrica e material parental, a formação de argilas 2:1 autigênicas (e.g. montmorilonita), não sendo, entretanto, verificadas nas amostras da presente investigação, mas sim, caulinita. Estascondições poderiam ser denominadas biostásicas, ou seja, haveria um equilíbrio nas inter-relações entre as variáveis envolvidas. Adicionalmente, segundo Ruellan (1986), as variações laterais nas toposseqüências são determinadas pela topografia. Sabe-se que, em geral, nesses tipos de seqüência todos os limites são dinâmi cos, e isso é muito importante para saber como e em que vel oci dade o limite de diferenciação lateral e vertical evolui.

As variações, principalmentelaterais, existentes entre os segmentos de meia vertente para a baixa vertente, no presente trabalho, mostram que os perfis de solos são imaturos, com ausência do horizonte $\mathrm{B}$, sendo classificados como Neossolo Litólico (VOVH3) e Neossolo Flúvico (VOVH4), contrastando fortemente com a dinâmica citada anteriormente por outros autores. Na baixa vertente da toposseqüência 3 , o perfil de base caulinizada e deferruginizada testemunha um paleoambiente de saturação hídrica, revelando um paleossistema de drenagem flúvio-lacustre.

Seguindo oraciocínio previamente exposto, a área de investigação do presente trabal ho mostra-se com pequenas, mas importantes diferenciações em relação aos modelos de dinâmica de vertente. Nas vertentes aqui estudadas, as variações laterais das características pedológicas apontam para uma ruptura entre os segmentos de vertente. Da alta para a meia vertente, há translocação de materiais com conseqüente acúmulo na meia vertente (colúvios), proporcionando o desenvolvimento de perfis latossólicos. Deste segmento para jusante, as variações laterais apontam para uma mudança. O coluvionamento deveria intensificar-se, mas nãoéo queseconstata nas três toposseqüências investigadas. A ausência detransição gradual a partir doambiente coluvial da meia vertenteem direçãoà planíce fluvial mostra um meio resistásico capaz de promover erosão no segmento de baixa vertente (saída do colúvio ali residente), desencadeando nova pedogênese, além de aumentar a declividade neste segmento, em relação à da meia vertente. A força motriz que proporcionaria energia para a transformação está relacionada com um encaixamento da rede de drenagem local (Ribeirão Maracujá toposseqüência 1 , e Córrego da Holanda toposseqüências 2 e 3, Figura 2) durante o Pleistoceno Superior e Hol oceno Médio (Valadão \& Silveira, 1992; Bacellar, 2000); fenômeno este também registrado em outras regiões de rochas do embasamento cristalino de Minas Gerais (Lichte, 1991; Moreira, 1992; Augustin, 1994).

O comportamento erosivo dos solos nas vertentes investigadas está relacionado com a erosão linear acelerada (voçorocas), cuja evolução parece não ter relação direta com as características pedogenéticas apresentadas, mas, sim, com a ocorrência de redes de fraturamentos e falhas observadas na área (Bacellar, 2000). Ou seja, após o encaixamento da rede de drenagem, as vertentes sofreram desequilíbrios hidrológicos de subsuperfície com o rápido rebaixamento do nível piezométrico. Assim, a movimentação hídrica subsuperficial concentrada em falhas e fraturas pode ter desencadeado os voçorocamentos a partir da baixa vertente, regredindo para montante até que os pontos de exfiltração hídrica nos talvegues das voçorocas ficassem em equilíbrio com o nível de base fluvial local (situaçãoatual), arrefecendo, consideravel mente, o ritmo erosivo das feições e proporcionando sua estabilização e col onização vegetal.

Desse modo, a ocorrência de voçorocas em vários estádios evolutivos parecenãoter relação direta com as características pedogenéticas apresentadas. A sua gênese está mais relacionada com as falhas e fraturas em conjunção com desequilíbrios hidrológicos subsuperficiais. A única influência pedogenética observada está relacionada com a ocorrência de solos pouco espessos na baixa vertente, cujo horizonte $C$ poderia ser mais facilmente interceptado pel a erosão superficial concentrada, fator desencadeador de voçorocamentos no sentido montante da vertente. Tal situação seria inteiramente plausível, pois o fluxo hídrico superficial chegaria ao segmento de baixa vertente com alto potencial erosivo maximizado pelo aumento da declividade. 
Não foram investigadas evidências que relacionam a vegetação atual (Cerrado degradado) ou pretérita com a evolução pedogenética.

\section{CONCLUSÕES}

1. Observações de campo, suportadas pel os dados micromorfológicos e mineralógicos, mostram uma ruptura na seqüência de transporte e deposição ao longo das três toposseqüências investigadas. Os produtos intempéricos produzidos no segmento de al ta vertente foram transportados e depositados no segmento de meia vertente, constituindo solos coluviais, cuja continuidade foi interrompida em direção ao segmento de baixa vertente.

2. N os segmentos de baixa vertente, observou-se a ocorrência de sol os pouco desenvol vidos (Neossolo e Cambissolo), em discordância com os modelos biostásicos clássicos, que apontam para uma zona de acumulação e autigenia mineral neste segmento.

3. Embora as toposseqüências investigadas estejam situadas em vertentes com diferentes graus de voçorocamento, as informações levantadas com base nas análises micromorfológicas, mineralógicas, químicas e físicas demonstram forte analogia pedogeomorfogenética entre elas.

\section{AGRADECIMENTOS}

\author{
À FAPEMIG, CAPES e CNPq, pelo suporte \\ financeiro.
}

\section{LITE RATURA CITADA}

AUGUSTIN, C.H.R.R. Amphitheaters and hollows with depositional sequences and their significance on the evolution of tropical landscape. In: INTERNATIONAL SEDIMENTOLOGY CONGRESS, 14., Recife, 1994. Anais. Recife, IAS/UFPE. 1994, p.G5.

BACELLAR, L.A.P. Condicionantes geológicos, geomorfológicos e geotécnicos dos mecanismos de voçorocamento na bacia do Rio Maracujá, Ouro Preto, MG. Rio de J aneiro, Universidade Federal do Rio deJ aneiro. 2000. 226p. (Tese de Doutorado)

BREWER, R. Fabric and mineral analysis of soils. New York, R.E. Krieger, 1976. 482p.

BULLOCK, P.; FEDOROFF, J .R.; J ONGERIUS, A.; STOOPS, G. \& GURSINA, T. Handbook for soil thin section description. Wolverhampton, WayneResearch. 1985. 157p.

CARSON, M.A. \& KIRKBY, M.J. Hillslope form and process. London, Cambridge University Press, 1972. 475p.

CASTRO, S.S. Micromorfologia de solos aplicada ao diagnóstico de erosão. In: GUERRA, A.J .T.; SILVA, A.S. \& BOTELHO, R.G.M., orgs. Erosão e conservação dos solos: conceitos, temas e aplicações. Rio de J aneiro, Bertrand Brasil, 1999. p.127-163.
CURI, N.; LIMA, P.C. \& LEPSCH, I.F. Terminologia de micromorfologia do solo. Boletim Inf. Soc. Bras. Ci. Solo, 10:33-44, 1985.

EMPRESA BRASILEIRA DE PESQUISA AGROPECUÁRIA EMBRAPA. Centro Nacional de Pesquisa de Solos. Manual de métodos de análise de solo. Rio de J aneiro, 1997. 212p.

ESWARAN, H. \& STOOPS, G. Surface textures of quartz in tropical soils. Soil Sci. Soc. Am. J ., 43:420-424, 1979.

FIGUEIREDO, M.A. Óxidos de ferro pedogênicos esua influência na agregação de partículas de argila: estudo de caso nos sol os da região de Gouveia - Serra do Espinhaço Meridional - MG. Belo Horizonte, Universidade Federal de Minas Gerais, 1999. 95p. (Tese de Mestrado)

FIGUEIREDO, M.A.; AUGUSTIN, C.H.R.R. \& FABRIS, J.D. Mineralogy, size, morphology and porosity of aggregates and their relationship with soil susceptibility to water erosion. Hyperfine Interact., 122:177-184, 1999.

FUNDAÇÃO CENTRO TECNOLÓGICO DE MINAS GERAIS CETEC-MG. Diagnóstico ambiental do Estado de Minas Gerais. Belo Horizonte, 1983. 158p.

LEMOS, R.C. \& SANTOS, R.D. Manual de descrição e col eta de solo no campo. 3.ed. Campinas, Sociedade Brasileira de Ciência do Solo, 1996. 84p.

LICHTE, M. Arid processes in the SE-brazilian relief evolution during the last glacial. Bol. IG/USP, 8:201-211, 1991.

LUCAS, Y. \& CHAUVEL, A. Soil formation in tropically weathered terrains. In: BUTT, C.R.M. \& ZEEGERS, H., eds. Regolith exploration geochemistry in tropical and subtropical terrains. Amsterdam, Elsevier Science Publishers, 1992, p.57-77.

MACIAS, F. \& CHESWORTH, W. Weathering in humid regions, with emphasis on igneous rocks and their metamorphic equivalents. In: MARTINI, I.P. \& CHESWORTH, W., eds. Weathering, soils and Paleosols. Amsterdam, Elsevier Science Publishers, 1992, p.283-305.

MILLOT, G. Planation of continents by intertropical weathering and pedogenetic processes. In: MELFI, A.J . \& CARVALHO, A., eds. INTERNATIONAL SEMINAR ON LATERITISATION PROCESSES. 2., São Paulo, 1982. Anais. São Paulo, IUGS-UNESCO-IGCP-IAGC, 1983. p.53-63.

MOREIRA, C.V.R. Fatores condicionantes das voçorocas na subbacia do rio Santo Antônio, bacia do rio Grande, MG. Belo Horizonte, Universidade Federal do Minas Gerais. 1992. 163p. (Tese de Mestrado)

OLLIER, C. \& PAIN, C. Regolith, soils and landforms. Chichester, J ohn Wiley \& Sons, 1996. 316p.

PARZANESE, G.A.C. Gênese e desenvolvimento de voçorocas em solos originados de rochas granitóides na região de Cachoeira do Campo, Minas Gerais. Viçosa, Universidade Federal de Viçosa. 1991. 117p. (Tese de Mestrado).

QUEIROZ NETO, J.P. Geomorfologia e Pedologia. R. Bras. Geomorfologia, 1:59-67, 2000.

RADAMBRASIL. Levantamento de recursos naturais. Fol has SF 23/24 - Rio de J aneiro/Nitória. Rio de J aneiro, IBGE, 1983. v.32. 767p.

RESENDE, M.; CURI, N.; REZENDE, S.B. \& CORRÊA, G.F. Pedologia: base para distinção de ambientes. Viçosa, NEPUT, 1997. 367p. 
RUELLAN, A. Soil vertical and lateral differentiation. Seminário IBSRAM, Khon-Kaen, 1986. p.155-168.

SALAROLI, I.S. Mapeamento litoestrutural da região de Santo Antônio do Leite - Ouro Preto. Ouro Preto, Universidade Federal de Ouro Preto, 1999 (Relatório do Trabalho Geológico de Graduação em Geologia)

SANDER, H. The porosity of tropical soils and implications for geomorphological and pedogenetic processes and the movement of solutions within the weathering cover. Catena, 49:129-137, 2002.

SEGOVIA, A.V.\& FOSS, J .E. Landforms and soils of the humid tropics. In: LA FLEUR, R.G., ed. Groundwater as a geomorfic agent, George Allen \& Unwin. U. S. A. 1984. p.78-90.

THOMAS, M.F. Ages and geomorphic relationships of saprolite mantles. In: ROBINSON, D.A. \& WILLIAMS, R.B.G., eds. Rock weathering and landform evolution. Chichester, J ohn Wiley \& Sons, 1994b. p.287-301.
THOMAS, M.F. Geomorphology in the tropics: a study of weathering and denudation in low latitudes. Chichester, J ohn Wiley \& Sons, 1994a. 460p.

VALADÃO, R.C. \& SILVEIRA, J.S. Estratigrafia quaternária e evolução do rel evo no Compl exo Bação: dados preliminares. In: SIMPÓSIO DE GEOLOGIA DE MINAS GERAIS, 6., Ouro Preto, 1992. Anais. R. Escola de Minas, 45:85-87. 1992.

VIDAL-TORRADO, P. \& LEPSCH, I.F. Relações material de origem / solo e pedogênese em uma seqüência de solos predominantemente argil osos e latossól icos sobre psamitos na depressão periférica paulista. R. Bras. Ci. Solo, 23:357359, 1999.

VILELA, R.A. Geologia de um segmento do Complexo Matamórfico Bação: área entre Glaura e Cachoeira do Campo, Quadrilátero Ferrífero, Minas Gerais. Ouro Preto, Universidade Federal de Ouro Preto. 1999 (Relatório do Trabalho Geológico de Graduação em Geologia)

YOUNG, A. Slopes. London, Longman, 1972. 288p. 